\title{
Impaired cognitive function in healthy offspring of bipolar patients
}

\author{
Agnieszka Permoda-Osip ${ }^{1 *}$, Alina Borkowska ${ }^{2}$, Janusz K Rybakowski ${ }^{1}$ \\ From $1^{\text {st }}$ International Congress on Neurobiology and Clinical Psychopharmacology \\ and European Psychiatric Association Conference on Treatment Guidance \\ Thessaloniki, Greece. 19-22 November 2009
}

\section{Background}

Several recent papers report on impaired of cognitive functions in healthy offspring of patients with bipolar mood disorder [1-3]. The aim of this study was an assessing of the performance on the Wisconsin Card Sorting Test (WCST), measuring executive functions, in the offspring of bipolar patients compared with genderand age matched healthy subjects.

\section{Materials and methods}

Fifty persons (17 male, 33 female), aged 18-52 (30 \pm 7 ) years made the total adult offspring population of patients with bipolar mood disorder. Among them, two had a history of depressive episodes, and another eight scored positively on Mood Disorder Questionnaire [4]. The head-to-head age- and gender-matched healthy subjects were used as a comparison group. The computer version of WCST designed by Heaton et al. (1993) adapted with instructions in Polish was used in all subjects. The following domains of WCST were measured: the percentage of perseverative errors (WCST-P), the percentage of non-perseverative errors (WCST-NP), the number of correctly completed categories (WCST-CC), the percentage of conceptual level responses (WCST-\% conc), and the set to the first category (WCST-1st cat).

\section{Results}

The results in the total offspring group were significantly inferior compared to matched control group in the categories of perseverative errors (WCST-P) and conceptual responses (WCST-\%conc). These differences remained significant after Bonferroni correction. The offspring of patients with some affective morbidity $(\mathrm{n}=$ 10) did not show differences with forty healthy patients.

\footnotetext{
${ }^{1}$ Department of Adult Psychiatry, University of Medical Sciences, Poznan,
} Poland

\section{Conclusions}

The results of our study show the impairment of some aspects of executive functions, connected with prefrontal cortex activity, in healthy offspring of bipolar patients.

\section{Author details}

'Department of Adult Psychiatry, University of Medical Sciences, Poznan, Poland. ${ }^{2}$ Clinical Neuropsychology Unit, Nicolaus Copernicus University Torun, Collegium Medicum, Bydgoszcz, Poland.

\section{Published: 22 April 2010}

References

1. Bio DS, Rocca CCA, Petresco S, Kreling R, Gutt E, Moreno RA: Neuropsychological evaluation in the offspring of parents with bipolar disorder. World J Biol Psychiatry 2007, 8(suppl 1):100-101.

2. Clark L, Sarna A, Goodwin GM: Impairment of executive function but not memory in first-degree relatives of patients with bipolar I disorder and in euthymic patients with unipolar depression. Am J Psychiatry 2005, 162:1980-198.

3. Gotlib IH, Traill SK, Montoya RL, Joorman J, Chang K: Attention and memory biases in the offspring of parents with bipolar disorder: Indications from a pilot 10 study. J Child Psychol Psychiatry 2005, 46:84-93.

4. Heaton RK, Chelune GJ, Talley JL, Kay GG, Curtis G: Wisconsin Card Sorting Test Manual. Psychological Assessment Resources, Odessa, Florida 1993.

doi:10.1186/1744-859X-9-S1-S159

Cite this article as: Permoda-Osip et al: Impaired cognitive function in healthy offspring of bipolar patients. Annals of General Psychiatry 2010 9(Suppl 1):S159.

Submit your next manuscript to BioMed Central and take full advantage of:

- Convenient online submission

- Thorough peer review

- No space constraints or color figure charges

- Immediate publication on acceptance

- Inclusion in PubMled, CAS, Scopus and Google Scholar

- Research which is freely available for redistribution 